\title{
Too Late Now: Libraries' Intertwined Challenges of Newspaper Morgues, Microfilm, and Digitization
}

Many major newspapers once produced and distributed different editions of a newspaper for different markets on the same day. This publication arrangement lasted for about a century, from the Gilded Age of the 1880s until business consolidation happened in the news industry during the 1970s and 1980s. ${ }^{1}$ The contents of the editions of the same newspaper could vary widely. The existence (and disappearance) of simultaneous newspaper editions represents one of the greatest documentary challenges facing present and coming generations of genealogists, local communities, and social historians. This article provides an argument to pay attention to three interrelated issues facing librarians today: first, an overlooked collection issue related to newspapers and special collections librarianship; second, why newspaper microfilm may not be an adequate substitute for print; and third, why digital options may not be adequate substitutes for newspaper microfilm.

This is a situation that has evolved over time and rests on more than newspaper publication practices. As custodians of the material from which the local and national past is told, it is now very much a practical matter for libraries today. The story involves choices made when newspapers were microfilmed and involves libraries again as microfilm becomes the platform for creating new digital resources. Since microfilm is a widely trusted medium in libraries, and since digital access to increasingly large and detailed databases is being similarly adopted, why would either newspaper microfilm or digital databases be a potential issue of concern to special collections libraries? Truthfully, it may not be. This article is not a systematic study of a general problem. It is, rather, a description of interrelated premises and choices that libraries face to maintain newspaper morgues and newspaper microfilm collections, as well as adopting databases as a replacement for historic newspapers.

To understand the interrelated issues (no newspaper pun intended), we have to explore the beginning of the problem, almost to the beginning of special collec-

1. Newspaper editions are not gone. Digital technology allows publishers to produce and send files for print distribution to other markets. The New York Times, for instance, still produces multiple editions for regional markets. The challenges of capturing and preserving digital-only formats like news blogs is an entirely separate issue with similar challenges. 
tions libraries and modern academic library departments in the 1930s and 1940s. Anyone who has watched Orson Welles' film Citizen Kane recalls one of the film's premises: that newspapers are a business. They put out a product on a weekly or daily basis and, like most businesses, expanded and contracted their product line where consumer interest translated into sales. As the Industrial Age progressed and printing presses got both larger and faster, the time needed to print a single issue declined even as circulation numbers increased. An idle press is not a cost-effective investment, so one means of increasing the return on investment for many large newspapers was to create for readers different options in their product line. One early example is the Deseret News, published in Salt Lake City since 1850, which was originally a weekly newspaper. The News became a daily newspaper in the 1870 s for a growing urban market but continued the weekly edition for distribution in outlying towns. By 1900, the company also published a semiweekly issue, plus a railroad edition for distribution on transcontinental trains. Its chief competitor, the Salt Lake Tribune, began as both a daily and a weekly edition. Another newspaper might choose differently. In Nashville, Tennessee, the Tennessean's market solution was to publish both the Tennessean for morning delivery and the Evening Tennessean. ${ }^{2}$

Prior to the digital age, newspapers functioned as the Internet of the day, a hardcopy combination of news feed, social media, and pop-up advertising. Even so, one size did not fit all. Publishing various editions represented a manual means of generating salable data for diverse readerships. As newspaper printing plants and distribution networks expanded in the late nineteenth century, the number of editions a large newspaper printed often expanded and specialized as well. The Pittsburgh Courier is a good example from the mid-twentieth century. The Courier is a major resource for the history of black America because the paper(s) employed and published the reportage of traveling correspondents and because its editions published local-item news far afield from Pittsburgh, Pennsylvania. Catalogue records from the Library of Congress, the basis of most libraries' records, states merely "Numerous editions." In fact, according to contact information in its own masthead and editorial pages at various times, the newspaper was published and distributed in no fewer than eight editions for separate but overlapping regional markets: National, Southern, Georgia, Louisiana, Ohio, New York, Northeastern, and Midwestern editions, plus a Local (later City) edition for Pittsburgh and the surrounding area. It was also dressed in separate urban editions for Detroit, St. Louis, Chicago, Phila-

2. J. Cecil Alter, Early Utah Journalism (Salt Lake City: Utah State Historical Society, 1938), 300-06, 352-60; Wendell J. Ashton, Voice in the West: The Biography of a Pioneer Newspaper (New York: Duell, Sloan \& Pearce, 1950); O.N. Malmquist, The First One Hundred Years: A History of the Salt Lake Tribune, 1871-1971 (Salt Lake City: Utah State Historical Society, 1971). The Tennessean published an evening edition between 1918 and 1937. The film of the morning and evening editions is available at the Tennessee State Library and Archives and Nashville Public Library_-but the existence of multiple editions is not well understood since none are noted in the master list of state newspapers (see www.tn.gov/tsla/history/newspapers/paper-n.htm). 

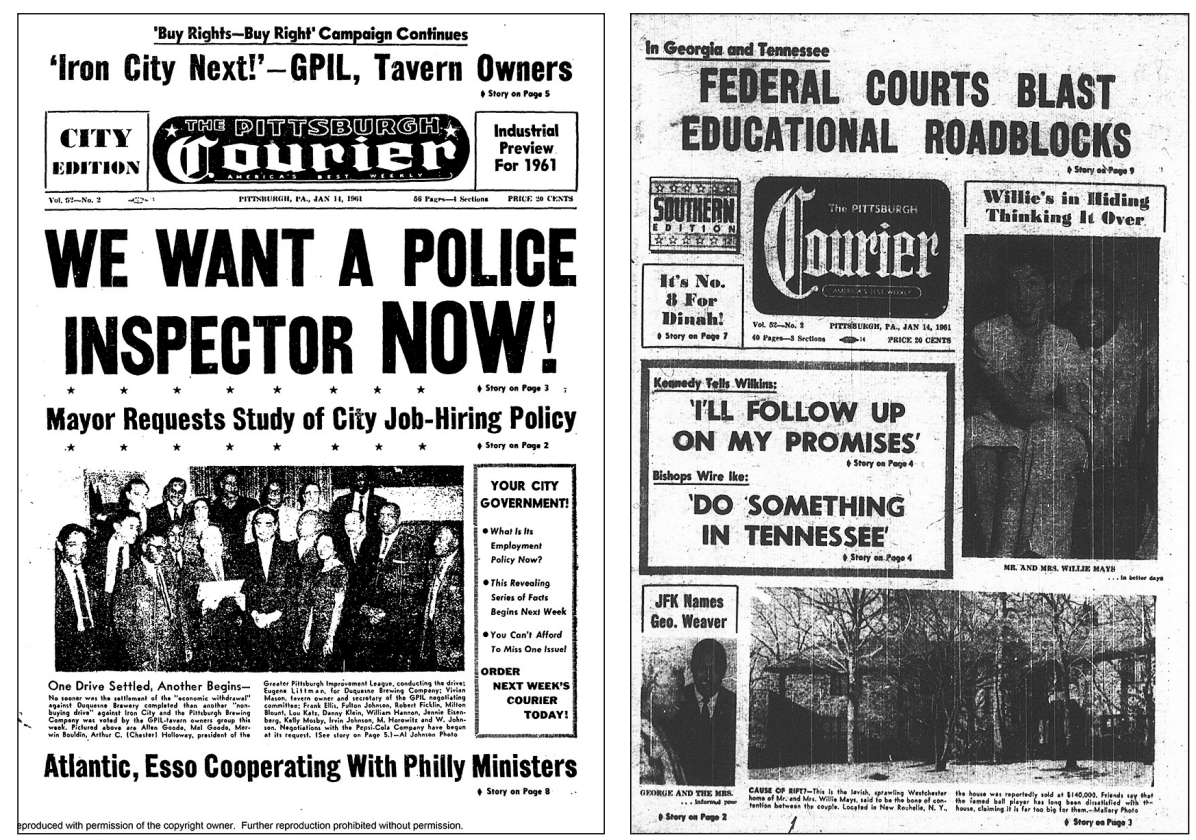

FIGURES 182. Front pages from two editions of the Pittsburgh Courier, both dated 14 January 1961: City (left) and Southern (right). The edition is indicated directly to the left of the masthead. Despite identical titles and issue dates, content often varied widely between multiple editions (Reproduced courtesy of ProQuest and the Pittsburgh Courier).

delphia, and Washington, D.C. markets-all editions distributed to newsstands and subscribers in individual locales under the same newspaper title. ${ }^{3}$ Check any of the same-date issues from two editions and most of the content, page layout, and advertising is guaranteed to be different. In practice, the article duplication between the City and Southern editions of the Courier might total two stories, one of which is severely edited for length. I have not yet found an example of outright duplication between the editions. In practice, more than a dozen different newspapers were published by the firm, each with a high percentage of content unique to its circulation market. In its heyday, the Pittsburgh Courier may have been distributed and read more widely and by a larger population than its better-known competitor, the Chicago Defender, which published its own multiple editions.

What did the existence of multiple newspaper editions mean to libraries? Maintaining a print newspaper collection in a library has always been difficult and expensive, at best. Their sheer size complicates housing and use. The folded sheets of news-

3. Not all editions were simultaneously or continuously published over the lifespan of the newspaper, which is still actively publishing. An edition could circulate for a few years before being dropped as the market shifted. 
print are inconveniently large, have no covers to reinforce or protect them, and accumulate alarmingly. Issues also came out with rapidity, were used intensely for a comparatively short period, and then became so much old paper. Newspapers' value as a social and historical record often required the passage of years or generations. Meanwhile, housing and preserving newspapers was expensive. Acquiring and housing multiple editions of the "same" newspaper only multiplied libraries' budgets and space challenges arithmetically. Within a few decades of the twentieth century, it was clear that bound library collections of print newspapers were unsustainable in terms of both growth and physical preservation. For example, by 1939, the University of Illinois newspaper library held merely 455 titles but over 20,000 oversize bound volumes. " "Permanent" newspaper collections threatened to expand to the point of being unsustainable. As a result, most institutional collections tended to bind and house only a few newspapers. Of local newspapers, libraries tended to keep what was most important to a branch, a city, or that end of the state.

\section{Newspapers and Microfilm}

Fortunately, by 1939 a new technology—microfilm—looked like a timely solution to shrinking available space that seemed to resolve the concerns about maintenance and space costs that made preservation of print newspapers problematic. Large institutions and state libraries began converting print newspaper holdings to microfilm in the late 1930s almost as soon as the technology was developed. Faced with swelling newspaper collections that filled shelf and floor space with alarming speed, microfilm was a means to consolidate, inventory, and eventually replace newsprint spilling off shelves and out of basements and closets. For libraries that did not maintain print newspaper collections, microfilm was an inexpensive option to acquire important documentary records. Tattered volumes, rolls, and bales of historic newspapers filled the basements of universities, courthouses, and local libraries across the country, and by 1940 professionals were already talking about microfilm as an adequate, accessible, and perhaps preferable library substitute for collections of print newspapers. ${ }^{5}$ Libraries made the change fairly quickly, and microfilm essentially replaced binding for current and even historic, often unique, newspaper files by the 1950 s.

4. L.L. Qualls, "Newspapers in the University of Illinois Library," Illinois Libraries 24 (1942 May): 71-77.

5. A.F. Kuhlman, "Administration of Serial and Document Acquisition and Preparation," in W.M. Randall, Acquisition and Cataloguing of Books (Univ. of Chicago Press, 1940), 95-116; C.S. Paine, "Microfilm in the Small College Library," C $\mho R L ~ 3$ (June 1942): 224-29 provides cost comparison figures for print and microform (in 1942). Nicholson Baker, Double Fold: Libraries and the Assault on Paper (New York: Random House, 2001) controversially but pointedly addresses libraries' handling of newspaper collections specifically, reprising in much more specific and updated terms a classic indictment by Randolph G. Adams, "Librarians as the Enemies of Books," Library Quarterly 7 (1937): 317-31. I strongly encourage readers to familiarize themselves with Baker's arguments. 
Microfilm is not a consumer product, but it is a commercial retail product. With the possible exception of a very few scholars, microfilmed newspapers (and manuscripts) were sold almost exclusively to libraries. Libraries, therefore, had to buy their microfilm as duplicates of what film negatives were available. Microfilm made it possible for libraries to make available much more historical source material than they could have owned and housed economically in print. From the 1950s to the 1990s, microfilm was a booming library business - and it was a business. In the midst of adopting microfilm as a storage/access medium, mid-century librarians were aware of the challenge that multiple-edition newspapers posed to preserving newspapers as historical sources, but they were not the only decision makers involved in the process. We should remember that commercial microfilming was a business venture, and reducing overhead and eliminating low-demand products are measures to maintain solvency—not judgments about objective documentary integrity.

In local microfilming services in almost every state (which was sometimes the state library), with few exceptions the most expedient filming policy was to reduce the investment of microfilm by limiting microfilming to one of the last editions of the day for a given newspaper. Most often the edition chosen was the day's "final" edition, the last edition produced during a day for an afternoon newspaper. We could guess that it was simply a decision of expedience-what edition of a newspaper a filming firm could get delivered to their market by basic subscription. In reality, there are probably no recorded justifications for why or how any given microfilm firm chose particular editions for filming, but the choice has long consequences for researchers who use them.

Occasionally, a newspaper itself or a library might preserve or pay to buy the film of multiple editions. One example is the Brooklyn Daily Eagle from the New York borough of the same name. The commercial microfilmer produced separate negatives for the First Edition, M-X, Wall Street, and Sports Final editions. ${ }^{6}$ Microfilming all editions of a newspaper usually seemed like an expensive and unnecessary investment for microfilming companies and for their institutional patrons. That small fact is important: once a microfilm company limited their commercial output to one out of a newspaper's several editions, the likelihood that individual libraries could or would retain other editions, or that another microfilm service would even film them, dropped dramatically.

\section{Implications of Microfilm}

In the moment, however, choosing to film a broadly distributed state edition (because a state edition would likely be the most widely read) or "final" edition

6. The Brooklyn Collection of the Brooklyn Public Library retains separate film of each edition (personal communication, Oct. 15, 2014). 
seemed a reasonable enough measure. In a day before news feeds and desktop computers kept everyone connected to the world beyond their door, work settings were isolated islands. Workplace radios and television were uncommon. The afternoon or evening newspaper was the first opportunity for working men to see what the day had brought. Thus, microfilm companies and librarians were partly correctbut they overlooked what was not in the pages; like the NBC Nightly News, final editions tended to summarize national and international news wires. Librarians did not seem to realize that most late-edition newspapers were titled "final" chiefly because they contained closing-bell reports from national financial markets, not because the reportage in them was cumulative. Worse, while various editions of a newspaper often shared some common content, most articles-especially local stories - appeared uniquely in only one edition, or were shared between only two or three regional editions, usually under different titles and invariably edited to fit the available column space. ${ }^{7}$ Editors culling the most important community news for the daily "final edition" preferred business, political, and infrastructural newsthe types of things of interest to businessmen returning home from the workday. Local stories tended to be viewed as less significant than "big picture" stories from the newswires.

That detail is important to present-day librarians and researchers for two reasons. First, it means that these types of "big picture" stories in final editions are also the most likely stories to appear in other newspapers on the same day, lessening the importance of any one final-edition newspaper as a means of portraying (and preserving) what was happening within a community itself; front-page and first-section content became fairly standard, since newspapers tended to report the same national and international stories, especially if the paper relied on newswire releases. That makes the general newspaper content of "final editions" neither unique nor important, merely newsworthy. Second, it means that final-edition content tends to be the most regionally ephemeral news, of little value beyond the moment. In terms of their collections, librarians concluded that buying microfilm of a newspaper by title was enough to preserve an "entire" newspaper; or it meant they consciously decided (after careful comparison, one would hope) that variant editions did not have enough unique content to merit the expense and space of another set of microfilm. Unfortunately for today's researchers, that means that most of the really valuable social documentation in local and regional newspaper editions - those that concentrated uniquely on news with the greatest value to readers of later generations-were well-intentionally ignored in microfilming. Most

7. This is an experience-based observation and is difficult to document adequately on the scale it occurred, since each newspaper handled editorial policy, publication standards, and editions independently. Documenting exactly why and to what extent duplication and nonduplication existed would be impossible, because every newspaper had its own editions and there was no uniform policy. The balance of the paper includes a few comparative examples as illustrations. 
never made it to a library collection and are known chiefly and ephemerally from scrapbook clippings.

By the 1960s, libraries and librarians had seemingly forgotten about newspaper editions or were resigned to accept the premise of unavoidable loss that was the foundation of newspaper microfilming. Not a single article in indexed professional library literature challenged the assumption that microfilming one edition of a newspaper sufficiently preserved a newspaper's varied record of its editions. Not everyone accepted the premise, however. It was clear to professional indexers that best practices for newspaper microfilm unavoidably failed to preserve valuable, often unique stories that appeared in editions that were not microfilmed. As early as 1965, New York Times Index editor John Rothman noted that microfilming practices preserved only part of the content of the several editions that his firm produced. ${ }^{8}$

There are isolated exceptions to that general loss. The Brooklyn Daily Eagle is unique in that most or all of its editions were captured by a single microfilm service. Occasionally_very occasionally—separate editions of a newspaper might have been microfilmed by different services or institutions, a rare circumstance that both enables and complicates the survival of multiple editions. Despite what OCLC holdings records state, most of the Pittsburgh Courier editions seem to have disappeared entirely from libraries and from history, casualties of their ephemerality and of the tradeoffs necessary to maintain collections within library budgets and walls. If a newspaper title was commercially available on film, why pay to have the local subscription microfilmed separately? In the Pittsburgh Courier's case, the Microfilm Corporation of Pennsylvania filmed the City edition, a task later assumed by UMI. Then it also handled the National edition, which was microfilmed to the end of 1960; thereafter the paper's Southern edition was filmed (a fact that is not noted in catalogue records I have found). That's all. Most of the baker's-dozen editions of the Pittsburgh Courier - and their broad documentation of regional black America-are gone. Therein lies the cautionary lesson for modern libraries: unless a microfilmer captured more than one edition, or in the unlikely event that multiple microfilmers captured different editions of a newspaper, microfilming condemns multiple-edition newspapers to oblivion. In other words, check your microfilm carefully because it may be unique.

As we move into a new century, the problem worsens. Outright errors in catalogue records lay a foundation for a new series of ill-informed collection decisions. For instance, OCLC's WorldCat database includes records for several editions of the Courier. However, in the public screens, OCLC displays the same aggregated

8. John Rothman, "Preserving the News That's Fit to Print," Saturday Review, Sept. 13, 1965; reprinted, Indexer 5, no. 1 (Spring 1966): 39-42. 
holdings record for each edition's record, displaying a message (as of March 2015) "Displaying libraries 1-6 out of $\mathbf{3 3 4}$ for all $\mathbf{3 4}$ editions." At first glance, displaying the aggregated holdings makes it appear that any one local/ regional newspaper microfilm is held much more widely than it actually is, and that the different editions are, in fact, available to researchers when they may not be. In other words, the largest resource-sharing tool and a large number of cataloguers have inadvertently created the illusion that the ephemeral regional editions of the Pittsburgh Courier are widely available. ${ }^{9}$ Based on those holdings, informed retention decisions for a microfilm collection could be compromised.

\section{Implications of Newspaper Digitization}

The Pittsburgh Courier provides another cautionary example, as the preservation of social and economic history in newspapers is being further complicated by the newest rush to new technology: digital image databases. The modern analog to the creation and adoption of newspaper microfilm in the 1930s is the creation of databases as commercial products in the 2000s. Libraries are now rushing or being pushed toward commercial digital services as born-digital newspaper imaging is aggregated in databases rather than being run to microfilm. Like its microfilm predecessor, digital platforms are often considered a suitable, even desirable replacement for ephemeral and often increasingly fragile matter like print newspapers and for microfilm collections nearing the end of their usable (and legible) lifespans. In digitizing historic newspapers, commercial database vendors tend to capture page images from microfilm rather than from bound volumes (and yes, there are exceptions). In the case of the Pittsburgh Courier, the digital edition presently available through the ProQuest database is a filming of the City edition, which has virtually no content from beyond Pittsburgh itself. ${ }^{10}$ A library anywhere other than Pittsburgh that expects to replace its microfilm of the Courier (which is almost certainly the National or Southern edition film) with database access would do future

9. For instance, at least in the public screens the system initially displays an aggregate list of institutional holdings records, no matter what edition of a newspaper is chosen. I confirmed the holdings of three editions: New York, Georgia, and St. Louis—but, other than the Pennsylvania Newspaper Project, none of the institutions I contacted to confirm the holdings actually had film of any of the three editions their record showed they held; the film was typically the National or City film on the shelves. The OCLC link option to "Show libraries holding only this edition or narrow results by format" will restrict records to entered holdings of specific editions, but a check of the libraries suggests that holdings records have, for whatever reason, not been appended carefully. For instance, some editions with holdings appended do not appear in the catalogue of any institution that has attached a holding record to the edition. My point is simply that there is no adequate way to document exactly what regional editions exist with current tools, short of a reel-by-reel, institution-by-institution search to confirm what the film actually shows - which is utterly impractical unless institutions recheck and update their own holdings in OCLC.

10. The weekly Pittsburgh Courier is digitally accessible through ProQuest's Historical Newspapers, Black Historical Newspapers, and Black Studies Center; it is cited as an example, not an indictment, of ProQuest's product. The City or Local edition (through various title changes) is captured between 1911 and June 1981; after July 1981, content is from the National edition. As of the publication of this article, no Courier edition is included in the Newspaper Archive (see http://newspaperarchive.com). 
students a disservice. Other than an occasional clipping and the National/Southern and City edition film, once available from the Microfilm Company of Pennsylvania negatives, none of the reportage from other Pittsburgh Courier editions survives on either edition's film; it is therefore not in the modern newspaper database. In changing access to historic newspapers from scattered microfilm reels to singlesource digital platforms, it is quite possible that the working assumptions of "completeness" and "preservation" may work against users of particular newspapers. Large digitization projects like the Library of Congress's Chronicling America and commercial newspaper databases like the Newspaper Archive may in fact encourage a second round of American newspapers' disappearance. ${ }^{11}$

\section{Clipping Morgues}

If microfilm and digital databases are not adequately preserving the varied content of newspaper editions, what else might preserve the unique contents of twentieth century newspapers? Budget-weary and space-crunched library administrators typically don't like the answer: it may be that the few bulky, messy, fragile, and deteriorating clipping morgues are perhaps the last remaining option for preserving variant-edition newspapers, and they are a scarce option, at that. This is not an option to broaden access or regain what has already disappeared; what is gone is gone, but there are sound reasons to plan carefully to preserve the few morgues that have survived.

Large newspapers (like the Memphis Press-Scimitar or Los Angeles Examiner) often maintained an internal clipping morgue for at least part of their history. Morgues acted as manual databases. Files of dated clippings allowed a newspaper to break its very chronological product (newspaper issues) into thematic parts (individual stories) for collocation and later retrieval. Morgue clipping files provided quickly retrievable background for reporters working on current stories. Until digital technology populated every desktop with a computer, clipping morgues often provided the only practical method for access to a newspaper's past subject content. Only the largest newspapers, like the New York Times, could afford to assemble and distribute an index.

\footnotetext{
11. The literature on the shift to digital in newspapers is voluminous and cannot be surveyed adequately here. The move to digital is already affecting newspapers' key elements as a documentary record. cf. Keith Greenwood, "Digital Photo Archives Lose Value a Record of Community History," Newspaper Research Journal 32, no. 3 (Summer 2011): 82-96. In discussing newspaper digitization projects, Patrick Reakes and Marilyn Ochoa, "Noncommercial Digital Newspaper Libraries: Considering Usability," Internet Reference Services Quarterly 14, no. 3/ 4 (2009): 92-113 note specifically that "Preliminary results from the small sample group surveyed indicate that for a variety of reasons testing is often underemphasized" (abstract). As nearly as I can tell, checking for the accessibility of variant editions is not included in the "Guidelines for Preservation Readiness of Digital Newspapers." cf. Nick Krabbenhoeft, Katherine Skinner, Matt Schultz, and Frederick Zarndt, "Chronicles in Preservation: Preserving Digital News and Newspapers," Preservation, Digital Technology \& Culture 42, no. 4 (Nov. 2013): 199-203.
} 
Unfortunately, the economics of the news industry have been such that clipping morgues have not survived well at all. As circulation declined and newspapers consolidated and folded during the 1980s (newspaper pun intended), both a newspaper's bound morgue, if it had maintained one, and its clipping morgue were often discarded. Only occasionally were they transferred to a local institution like a public or academic library. Still later, librarians sometimes assisted in destroying the few remaining bound-newspaper morgues - which might have preserved the content of multiple editions - in favor of microfilm (again, often because of pressing space issues), which left posterity with only a title, not content. If a clipping morgue does survive in an institution, it is likely more significant than either librarians or users may realize. Let me illustrate with a firsthand experience how significant a clipping morgue can be, and how morgues can reflect the practice of multiple newspaper editions and libraries' collections of newspaper microfilm.

Several years ago I was using the Memphis Press-Scimitar clipping morgue at the University of Memphis. The newspaper, long one of the region's major documentary records, had closed in 1983 after six decades of publication. While divesting its assets, a clipping morgue of more than five hundred cartons ungently crammed with subject-organized clippings and a detailed card index were deeded to the university. The card file was the only means of locating subject contents in the newspaper and in the morgue files. A few days after the visit, I needed to confirm a detail in one article from a morgue file clipping; and, since the newspaper staff had thoughtfully dated each of the clippings as it was filed a half-century earlier, I had the article title and date. Checking the microfilmed issue of the newspaper at my own institution, I found the article was not there. Checking a few other dated references on other clippings revealed similar inconsistencies: some of the articles from the morgue appeared in the microfilm, but not often. If I did find them, the articles on microfilm edition of the newspaper were typically shorter-often much shorter - than what I had found in the morgue clipping. Complicating things, they were almost always titled or laid out on the page differently from the clippings that existed in the morgue.

The morgue files had a few full pages folded up into their files that allowed me to compare full pages from the morgue with the microfilm on another visit. The few samples I could compare were completely dissimilar-almost another publication. In fact they were: there was more than one Memphis Press-Scimitar published every day, and the contents in the different editions did not seem to overlap much. 


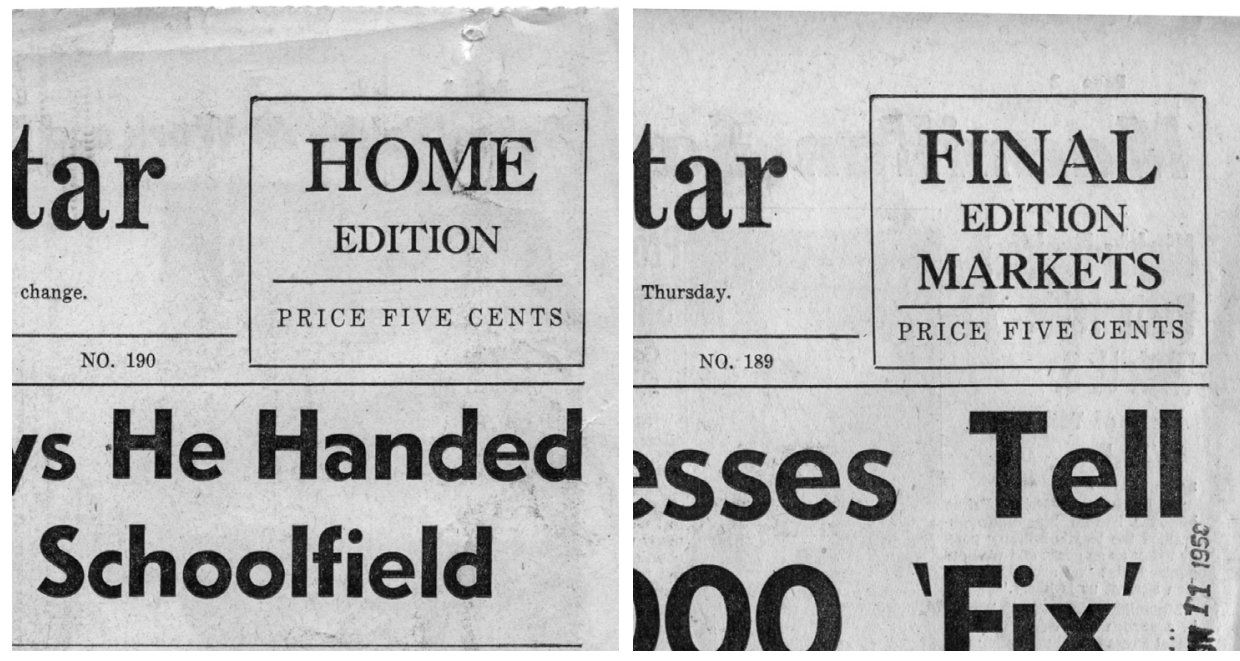

FIGURES 384. Front-page edition statements on two issues of the Memphis Press-Scimitar from January 1958. Newspapers could make edition statements in code as well, such as "Red-Diamond Edition" or "Three-Star Edition" (Courtesy of University of Memphis Special Collections).

It turned out that the microfilmed newspaper available to users in libraries was the "Final edition," while most of the clippings in the morgue files were from either the regional "Midsouth" or the city "Home" editions. Additional research and some calculations generated a grim estimate: it looked like only about $25 \%-30 \%$ of the stories in morgue clippings appeared in the microfilmed newspaper in any form at all. ${ }^{12}$ That meant $70 \%-75 \%$ of the five hundred cartons of clippings were the only copies of those stories extant. In other words, the ratty, well-thumbed folders filled with jumbled and torn newspaper clippings were absolutely irreplaceable - and the newspaper microfilm was a wholly inadequate documentary substitute.

\section{Interrelated Challenges}

Pulling together the themes of this article-newspaper publishing practices, twentieth-century microfilming, migration to digital formats, and the fortunate but scattered survival of clipping morgues-in retrospect, it seems that libraries' effort to preserve twentieth-century community and family history in newspapers have run aground on the law of unintended consequences. Newspaper

12. Most Press-Scimitar morgue files hold less than a one-inch stack of clipped material, stuffed into number-coded manila file folders and/or envelopes. I was using a rather unusual single file number that amounted to nearly an entire records center carton of clipped material, about 1.5 lin. ft., dating between 1956 and 1980. The estimate given here is based on what I found (and did not find) in that file and attendant microfilm, with spot checks from about a dozen other topical files in the morgue. This is a very small and nonrandom sample of a positively massive collection. Because every newspaper and every clipping morgue was published and filed differently, not every morgue would necessarily reflect the same ratios. 
editions with greatest value to the local communities they served have mostly disappeared in the first one-size-fits-all solution of microfilm; the few that did survive now risk disappearing under renewed broad expediencies of collection management or access. As a long-time archivist/special collections librarian and academic library administrator, I understand those realities; as a practicing historian, I am profoundly grateful that the local-history material supporting one facet of my work exists in a clipping morgue. Other researchers are not as lucky. Often only a single edition of most large newspapers exist for most readers, and the few newspaper clipping morgues that have survived are physically imperiled by use (both because they are acidic newsprint and because they tend to be handled ungently).

Clipping morgues are big and messy, and the contents are virtually impossible to police adequately, even in the supervised setting of a special-collections reading room. Their existence tends to be further threatened by a general lack of administrative understanding of just how precious morgues are, despite being large, unwieldy, and seemingly duplicative of microfilm. Newspaper morgues have been discarded all too often, and special collections risk becoming further perpetrators of this historical tragedy. Now the surviving record faces a new challenge. OCR technology and the ability to search digital content at the word level make voluminous and tattered subject-file clipping morgues seem obsolete. If newspaper content is retrievable at the word level, the reasoning goes, then the bulky files of deteriorating paper should be irrelevant.

The hope is that readers see that digital tools may provide speed and "access" but cannot index or recreate material that was not initially preserved or no longer survives. Unfortunately, the loss of history and source material in discarded newspaper morgues multiplies and threatens to expand with the eager adoption of digital imaging as a replacement for microfilm. The root problem is not with digital access per se, but with the idea that what little original material that does survive is no longer necessary because "we have digital access." A digital platform is a suitable replacement for either a run of microfilm or a clipping morgue only if the database includes all editions of a newspaper that are accessible in film or a morgue. The question of preservation and access is compounded, rather than simplified, when database vendors make expedient or uninformed choices about what newspapers to include in their products. At least in the case of newspapers, the rush to adopt digital resources renews a challenge to libraries as cultural and historic institutions, a challenge that repeats an earlier age and its rush to microfilm. "Sadly," writes Barbara Quint, "no matter what new policies and procedures may emerge in response to the dramatic changes in publisher practices in these challenging times, web-based content for the last half of the 
1990s and the first decade of the 21st century from established, high-quality publications has been lost forever." 13

\section{Options for Libraries}

So what do libraries do with racks of microfilm and the few newspaper and clipping morgues that remain? First, libraries should set aside the digitize-at-all-costs mentality that seems to have infected our profession. Libraries should acknowledge that physical media, both microfilm and morgue, may well be irreplaceable historical resources and not merely ratty, old, or outdated junk. If an institution houses a newspaper clipping morgue, it is almost certainly irreplaceable by any commercially available digital database or microfilm. Discarding it would be a breach of trust.

Second, if an institution houses a bound newspaper morgue, the library should invest time and effort to check morgue editions or clipped holdings against microfilm or digitally duplicated newspapers. Confirm whether or not all bound volumes are of the same edition, usually requiring no more effort than checking for an edition statement in mastheads and looking for an edition code, like a pattern or number of stars printed in the corners of interior pages. If the morgue is a clipping rather than bound morgue, spot-check extensively (perhaps with attention paid to sampling) to see that clippings are exactly those found in microfilm or digital resources. Fortunately, many morgue clerks used a date stamp to ensure clippings retained a publication date. That can provide a point to begin a search.

Third, if a clipping morgue does prove to contain a percentage of unique material, begin planning and budgeting for the preservation and conservation measures (and expense) that will eventually be required. Clipping and bound newspaper morgues are expensive to house, describe, and maintain — but it is difficult to put a price on "irreplaceable."

Fourth, short of mass deacidification and clipping-by-clipping repair, a project to digitize the unique morgue contents and retiring the original clippings from usenot discarding them - is a good way to maintain the resource while minimizing usedamage to already fragile clippings. Creating a digital simulacrum is no adequate substitute for taking care of the original item. As digitization proceeds, an easy way to set digitization priorities is by tracking the files that users request and then by capturing the files digitally before they are refiled.

13. Barbara Quint, "Where Have All the Archives Gone?” Information Today 26, no. 7 (Jul./ Aug. 2009): $1-39$. 

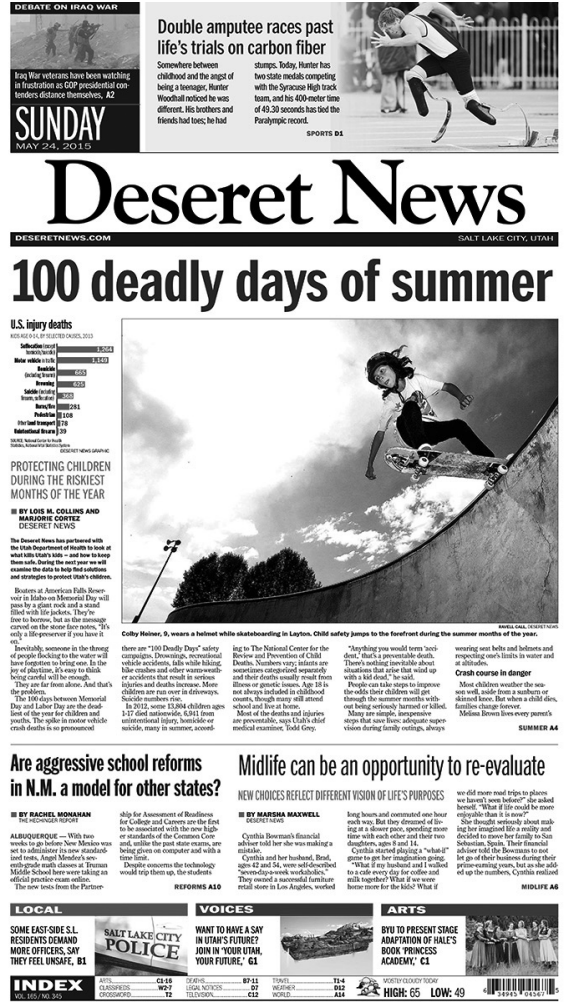
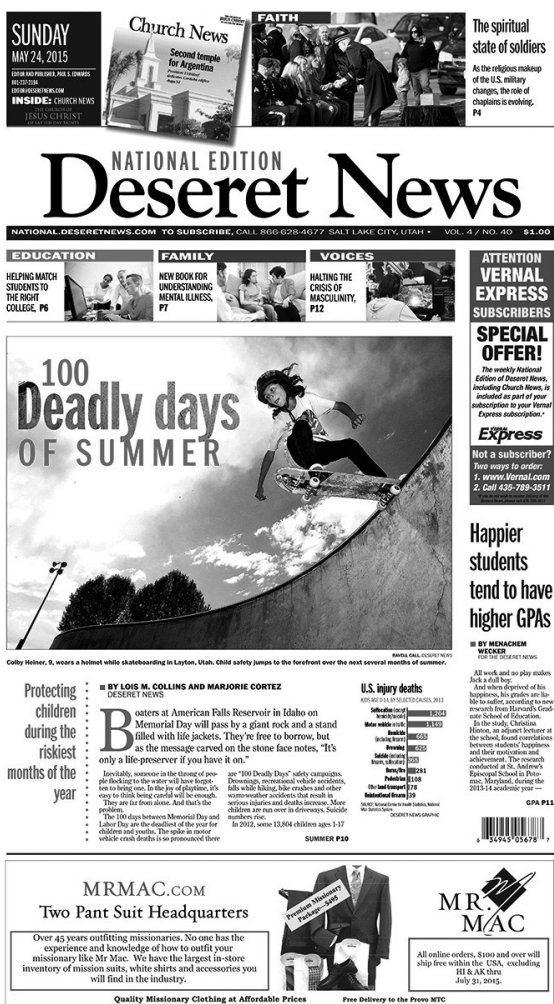

Figures 5\&6. Some, but not all, large modern newspaper publishers still produce multiple editions. Deseret News' Local (left) and National (right) edition front pages from 24 May 2015 (Reproduced courtesy of Deseret News Corp).

\section{Consequences}

Very rarely, a librarian finds at least a few issues of a regional newspaper edition that no other library holds and no researcher has used. Driving through a rural community east of Memphis, three years after my disturbing discovery about the loss of newspaper editions, I stopped at a consignment/antique store. Sitting on a chair inside were three bound volumes of the Memphis Press-Scimitar, three scattered but complete months of the newspaper's Home edition dating from the Second World War. The bindings showed that they had come from the newspaper's own bound-volume morgue, which had not gone to the University of Memphis with the clipping morgue. Looking through the pages, it was clear that the volumes were invaluable records, documenting home-front activities and providing data that did not even occasionally appear in the end-of-the-day news summary of the PressScimitar "Final edition." They were due to be offered in an Internet auction that evening. I tried to buy them outright or persuade the manager to postpone the sale for a guaranteed price, but they refused to budge. They were sold at auction; there is no record of where they are now. Sometimes libraries' and librarians' best efforts to preserve newspapers as documentary records are still subject to mischance. 